Article

\title{
International Business Research and the World Investment Report: "Big Questions" and Grand Challenges
}

\author{
Peter J. Buckley \\ 1 University of Leeds, UK \\ Keywords: multinational enterprises, global economy, development, foreign direct investment, grand challenges \\ 10.46697/001c.17987
}

\section{AIB Insights}

The World Investment Report (WIR) has sought "Big Questions" rather than Grand Challenges and has been entirely successful in mirroring the focus of international business (IB) research. It has not, however, focused on "Grand Challenges" deeming them to be beyond its remit, or too broad for a single report. There is no shortage of potential topics for future WIRs, building on past success and extant IB research.

\section{INTRODUCTION}

This piece argues that the World Investment Report (WIR) has sought "Big Questions" rather than Grand Challenges and has been entirely successful in mirroring the focus of international business (IB) research. It has not, however, focused on "Grand Challenges," deeming them to be beyond its remit, or too broad for a single report. The distinction between big questions and Grand Challenges is that big questions are framed in an academic agenda to be answered by careful investigation, whereas Grand Challenges come from the environment, do not necessarily have "answers", and are not easy to encompass even within a multi-disciplinary explanatory framework. These are societal, not academic challenges. Nevertheless these can be confronted by academic practices: theory, theory testing, and exploratory methods (Buckley, Doh, \& Benischke, 2017). This piece examines the 30 years of WIRs and examines the big questions that it has confronted - largely successfully. It then goes on to look at Grand Challenges that have only been partially confronted by WIR. The rise in Volatility, Uncertainty, Complexity and Ambiguity (VUCA) in the global economy and the increasingly fractured international economy and society into rival "camps" are new issues that will complicate the content of future WIRs as well as having a profound impact on international business in general.

\section{THE WORLD INVESTMENT REPORT AT 30}

The 30 volumes of WIR are a rich treasure trove of IB applied theory and policy-based empirical work. They have relied on leading IB academics for guidance on topics and implementation. A key influence for the first 20 years was John Dunning of the University of Reading. Dunning was a member of the "Eminent Person's Committee" who envisaged WIR and steered it as it became an annual publication and the key source of FDI data.

It has to be remembered that WIR, and UNCTAD, operate under political constraints (and restraints). This means that not all projects that academics champion are politically feasible as special topics for WIR. Among these are corruption, tax evasion and probably the Chinese Belt and Road Initiative. This is likely to be an increasingly serious issue in the future with the increasing fracture of the global economy under pressure from competing US and Chinese ambitions.

Nevertheless, the WIR has been able to tackle a number of big questions over the past 30 years. These issues have been identified by academic research in the main and so the history of WIR tracks the progress of international business research.

\section{“BIG QUESTIONS”}

WIR has been unafraid of tackling big questions, often before any firm resolution of the underlying academic enquiry, which makes some WIRs at the cutting edge of not only policy, but also international business research itself. The resolute focus of WIRs on development means that the external effects of MNEs are often to the fore in WIRs rather than the sometimes inward-looking research on "strategy". What follows is a necessarily abbreviated analysis of the big questions that WIR has tackled. The analysis builds on Buckley (2002) and Buckley et al. (2017).

\section{EXPLAINING FLOWS OF FDI.}

Early international business research was concerned with the nature, amount and directionality of FDI flows and its home country provenance. WIR has reflected this throughout its existence and the first WIR consolidated this research by concentrating on the Triad within which most source countries of FDI then existed -North America, Europe and Asia (then predominantly Japan)

\{WIR: 1991 The Triad in Foreign Direct Investment

\section{EXPLAINING THE EXISTENCE, STRATEGY AND ORGANISATION OF MNES.}

The focus of international business research moved rapidly from FDI flows to the organisation that controlled such flows - the multinational enterprise. WIR recognised the development impact of MNEs in its reports of 1992 and 1993, the employment implications of strategic decisions of MNEs and the importance of M\&As that have frequently accounted for $60 \%$ of total world flows of FDI.

\{WIRs: 1992 Transnational Corporations as Engines of Growth; 1993 Transnational Corporations and Integrated international Production; 1994 Transnational Corporations, Employment and the Workplace; 2000 Cross-border Mergers and Acquisitions\} 


\section{MOVING FROM INTERNATIONALIZATION TO GLOBALIZATION, “NEW FORMS” OF INTERNATIONAL BUSINESS OPERATIONS.}

As MNEs became more salient, international business researchers moved from the process of internationalization to examining the global operations of MNEs. The global competitive strategies of dominant firms, their impact on (and restrictions of) market structure, and their linkages in host countries that have important development effects have all been scrutinized. Sectoral study has been an important area of investigation for WIR including the directly development-orientated sectors such as extractive industries, infrastructure, and of course agriculture. These reports repay revisiting. Agriculture remains the most important sector in developing and least developed countries, extractive industries remain problematic and controversial, but are a key source of income for many poor countries. Infrastructure is again at the forefront of research, policy and discussion because of the impact of the Chinese Belt and Road Initiative.

WIR has traditionally had a central focus on Foreign Direct Investment, and it is the primary source of FDI data. However, FDI is only one tool in the MNE's strategic armoury. Moreover, to concentrate on FDI as representing the activities of MNEs is to underestimate their reach and power in the global economy. Consequently, WIR 2011 extended the reach of WIR by including non-equity modes of operation. Thus, licensing, franchising, and other contractual arrangements were included for the first time, giving a much more balanced view of MNE operations and strategy. This paved the way for seeing MNEs as the focal firms in global value chains (GVCs).

\{WIRs: 1995 Transnational Corporations and Competitiveness; 1997 Transnational Corporations, Market Structure and Competition Policy; 1998 Trends and Determinants; 1999 Foreign Direct Investment and the Challenge of Development, 2001 Promoting Linkages; 2002 Transnational Corporations and Export Competitiveness; 2004 The Shift towards Services; 2005 Transnational Corporations and the Internationalization of R\&D. The Sectoral studies are: 2007 Transnational Corporations, Extractive Industries and Development; 2008 Transnational Corporations and the Infrastructure Challenge; 2009 Transnational Corporations, Agricultural Production and Development. In 2011, Nonequity Modes of International Production and Development expanded the coverage of MNE strategies\}

\section{EXPLAINING THE EMERGENCE OF AND STRATEGIES OF MNES FROM EMERGING ECONOMIES.}

International business researchers saw the rise of FDI from emerging economies as a major change in globalization dynamics. They asked the key question of whether these "new" MNEs differed from established "Western" MNE's and, if so, in want way do they differ. The WIR of 2006 was an excellent consolidation of this work and moved it to the centre stage of development and policy thinking.

\{WIRs: 2006 FDI from Developing and Transition Economies - Implications for Development; 2019 Special Economic Zones\}

\section{EXPLAINING THE GROWTH, CAUSES, AND CONSEQUENCES OF OFFSHORING AND DISAGGREGATION OF VALUE CHAINS.}

The MNE is now envisaged in theoretical and empirical work, as not a free-standing entity but as the controlling centre of a network of inter-related businesses and other value-creating entities in a "global value chain". This value chain may be virtual, as well as physical, as the impact of the digitization revolution becomes apparent. Much on-going work needs to be synthesised and the reports of 2013 and 2017 respond to these big questions.

\{WIRs: 2013 Global Value Chains: Investment and Trade for Development; 2017 Investment and the Digital Economy)

\section{UNDERSTANDING HOW MNES RESPOND TO SOCIAL RESPONSIBILITY AND SUSTAINABILITY.}

MNEs are primarily business entities, but their actions and motives have non-market as well as market consequences. The upsurge of current research on "Corporate Social Responsibility" and related issues suggests that the big question of the role of business in society will continue to impact on FDI, MNEs and policy outcomes. The role of governance and its relationship with (foreign) ownership are ongoing topics of interest for WIRs.

\{WIRs: 2014 Investing in the SDGs - An action Plan; 2015 Reforming International Investment Governance; 2016 Investor Nationality - Policy Challenges; 2020 International Production Beyond the Pandemic\}

\section{APPRAISING POLICY TOWARDS MNES.}

A seventh theme, naturally, is policy towards MNEs. Policy is undergoing serious reappraisal in the face of political developments (the fracture in the global economy) and technological advances that are both pro-globalization (Blockchain) and anti-globalization (the "splinternet”). Issues regarding the implementation of "fair" taxation of global companies, and their development effects, will not become less salient. The rise of government macro-management of industrial structure and its ramifications is also a big question that looms ever larger as time and politics move on.

\{WIRs: 1996 Investment, Trade, and International Policy Arrangements, 1999 Foreign Direct Investment and the Challenge of Development, 2003 FDI policies for Development, 2010 Investing in a Low Carbon Economy, 2012 Towards a New Generation of Investment Policies, 2018 Investment and New Industrial Policies

$W I R$ has an excellent track-record in covering, and to a lesser degree, anticipating, big questions, but WIR and the whole United Nations system are faced with societal Grand Challenges, increasing VUCA, and the growing fracture in the global economy.

\section{GRAND CHALLENGES}

Grand Challenges are societal issues, broad based and not necessarily capable of solution. Moreover, they are difficult to deal with in a report that still has its main purpose of presenting the most comprehensive, accurate and up to date data on FDI. However, with the advent of COVID-19 and with the pressing challenge of climate change, WIR may be an ideal forum in which to discuss the relationship between 
foreign direct investment and these challenges, from a development viewpoint. Taking the impact of FDI on each individual Sustainable Development Goal (SDG) would be a good way to meet Grand Challenges.

In addition to the relationship between SDGs and FDI, a number of Grand Challenges suggest themselves as candidates for exploration in future WIRs. These include:

- Climate Change \{partially covered in WIR 20 on the Low Carbon Economy\}

- Poverty and Inequality, including gender and race.

- Migration

- Terrorism and Political Insecurity

- Literacy and Financial Literacy

- Mass Entrepreneurship

- Infectious Diseases e.g. HIV and Pandemics, COVID-19 fpartially covered, in a preliminary fashion, in WIR 30\}

For all these topics, it is possible to envisage a nexus between FDI, the Grand Challenge, and development.

On a more mundane, but well-researched area, WIR could examine the two-way relationship between SDGs and (global) business models. These issues affect business and are, in turn, affected by business practice.

\section{INCREASING VUCA IN THE WORLD ECONOMY}

Volatility, Uncertainty, Complexity and Uncertainty - VUCA elements are undeniably of increasing saliency in the modern global economy. The reaction of MNEs to one or more of these features could be a topic for WIR. The interconnected rise of VUCA elements as an interacting totality constitutes the Grand Challenge. The impact of rising VUCA on development and, in particular, for the Least Developed Countries is a splendid area for future research; research that probably has to lead any WIR on this pressing topic.

\section{THE FRACTURE IN GLOBALIZATION}

The world economy is increasingly bifurcated by policy-driven interventions between the USA and China. This covers not only trade, but also FDI, industrial policy, digital operations (creating the "splinternet") and other societal contacts such as education and culture (including the film and television industries). This division of the world into two competitive camps will profoundly affect the operations of international business, covering everything from restrictions on M\&As, reconfiguring of value chains, migration patterns, technology flows and security policies. This could be approached by comparing and contrasting the FDI patterns of China and the USA and how these relate to trade, knowledge flows, non-equity modes and development. This indeed could support several WIR reports. The UN has a vested interest in the rules-based system that has allowed the rise of global integration, particularly of regulation, and a WIR could be devoted to the impact and extent of its erosion on amounts, make-up and directionality of FDI flows.

\section{CONCLUSION}

There is no shortage of potential topics for future WIRs, building on past success and extant international business research. The global economy faces huge challenges COVID-19, the fracture in globalization, rising VUCA, and threats to the rules based system of trade and investment. $W I R$ will attempt to deal with these issues through its careful compilation of data and its presentation of special subjects. It can only do so much but, as part of the UN system, it is in a good position to confront grand challenges. This has to be a multi-year endeavour. As international business academics, we must support future efforts to the best of our abilities. The move from answering big questions to Grand Challenges is difficult for WIR, but UNCTAD can rise to the challenge.

\section{ABOUT THE AUTHOR}

Peter J. Buckley (p.j.buckley@lubs.leeds.ac.uk) is Professor of International Business, Centre for International Business, University of Leeds, Professor of International Business, University of Queensland and Visiting Professor at the Open University of Hong Kong. He is a Fellow of the Academy of International Business (AIB), Fellow of the British Academy of Management (BAM), Fellow of the Royal Society of Arts (RSA), Fellow of the European International Business Academy (EIBA), Fellow of the Academy of Social Sciences (FAcSS), and Fellow of the Japan Academy of International Business Studies. Peter was President of the Academy of International Business (2002-04), Chair of the European International Business Academy (2009-2012), appointed Officer of the Order of the British Empire (OBE) 2012 and elected a Fellow of the British Academy (FBA), 2014.

Submitted: September 01, 2020 EST, Accepted: November 13, 2020 EST 


\section{REFERENCES}

Buckley, P. J. 2002. Is the international business research agenda running out of steam? Journal of International Business Studies, 33(2): 365-373.
Buckley, P. J., Doh, J. P., \& Benischke, M. H. 2017. Towards a Renaissance in international business research? Big questions, grand challenges, and the future of IB scholarship. Journal of International Business Studies, 48(9): 1045-1064. 